\title{
PENYEBAB PERBEDAAN JUMLAH MAHAR DALAM KAWIN PINANG (PIKA BHEKA-BHEKA) PADA MASYARAKAT ETNIS CIA CIA (STUDI DI DESA WABULA KECAMATAN WABULA KABUPATEN BUTON PROVINSI SULAWESI TENGGARA)
}

\author{
Santi ${ }^{1}$, Salimin $A^{2}$, Irawaty ${ }^{3}$ \\ Jurusan Pendidikan Pancasila dan Kewarganegaraan \\ Fakultas Keguruan dan Ilmu Pendidikan \\ Universitas Halu Oleo \\ Email: santilaedi@gmail.com ${ }^{1}$, salimin@gmail.com ${ }^{2}$, irawaty@gmail.com ${ }^{3}$
}

\begin{abstract}
Abstrak: Tujuan dari penelitian ini yaitu: a. untuk mengetahui alasan terjadinya perbedaan Jumlah mahar dalam kawin pinang (pika bheka-bheka) pada masyarakat etnis Cia Cia di Desa Wabula Kecamatan Wabula Kabupaten Buton; b. untuk mengetahui proses penyelesaian perbedaan jumlah mahar dalam kawin pinang (pika bheka-bheka). penelitian ini dilaksanakan di Desa Wabula Kecamatan Wabula Kabupaten Buton Provinsi Sulawesi Tenggara. Jenis peneltian yang digunakan adalah jenis penelitian berdasarkan taraf penelitian yaitu penelitian deskriptif yang hanya menggambarkan keadaan objek dengan analisis kualitatif . Subyek penelitian ini terdiri dari 5 (lima) orang yang terdiri dari 2 (dua) orang tokoh ada Wabula sebagai orang yang mengatur tata cara adat dalam pelaksanaan perkawinan pinang (pika bheka-bheka), Kepala Kantor Urusan Agama (KUA) Kecamatan Wabula, 1 (satu) orang Imam/Khatib dan 1 (satu) orang Pegawai Pencatat Nikah (PPN). Teknik pengumpulan data yaitu: wawancara dan dokumenter. Hasil penelitian ini menunjukan bahwa perkawinan adat etnis Cia Cia menurut praktek hukum adat Wabula yang didasarkan pada stratifikasi sosial masyarakat etnis Cia Cia terdiri dari golongan Kaomu, Awalaka, dan Maradika. Adapun jumlah mahar dalam setiap golongan tersebut sangatlah berbeda-beda. Keturunan Sultan dan Sapati akan masuk dalam Kaomu (bangsawan) yang memiliki mahar 150 bhoka untuk jabatan Sultani dan 125 bhoka untuk jabatan Sapati. Golongan Awalaka merupakan golongan yang berasal dari keturunan Bontotoa (jabatan untuk kepala kampung) yang memiliki mahar sebanyak 100 bhoka. Sementara golongan maradika memiliki mahar 12 bhoka 4 kupa. Cara penyelesaian jumlah mahar untuk perkawinan berbeda golongan dapat diselesaikan dengan cara maradika manadikana (kesepakatan adat berdasarkan yang ditetapkan oleh tokoh adat) berdasarkan hukum adat yang berlaku. Kesimpulan dalam penelitian ini adalah bahwa perbedaan jumlah mahar yang terjadi pada masyarakat etnis Cia Cia menurut praktek hukum adat yang tidak tertulis disebabkan oleh stratifikasi yang terjadi di dalam suatau masyarakat tersebut yakni golongan Kaоmu, golongan Awalaka, dan golongan maradika. Perbedaan jumlah mahar pada masyarakat etnis Cia Cia dapat diselesaikan dengan cara mardika manadikana.
\end{abstract}

Kata Kunci: Perbedaan Jumlah Mahar, Penyelesaian Jumlah Mahar, dan Perkawinan Pinang

\section{PENDAHULUAN}

Indonesia adalah suatu negara yang pluralistik dari segi etnik dan kebudayaanya. Adat istiadat perkawinan adalah salah satu bagian dari kebudayaan tersebut. Dalam kebudayaan Indonesia, perkawinan merupakan hal yang sangat sakral dan selalu mengikuti pola budaya yang ketat sesuai ketentuan hukum adat tidak tertulis. Perkawinan bukan hanya bersatunya dua individu namun, lebih jauh adalah bersatunya dua keluarga besar. Perkawinan tidak boleh dilakukan serta 
merta dan tiba-tiba, harus menjalani beberapa proses sehingga sampai pada bersatunya dua sejoli dalam ikatan rumah tangga.

Perkawinan merupakan salah satu peristiwa penting dalam kehidupan manusia. Pada etnis Cia Cia perkawinan yang terjadi antara seorang pria dengan seorang wanita menimbulkan akibat lahir dan batin baik terhadap keluarga masing-masing maupun terhadap harta kekayaan yang diperoleh diantara mereka baik sebelum maupun selamanya perkawinan berlangsung. Perkawinan pinang (pika bheka-bheka) oleh masyarakat etnis Cia Cia dianggap sesuatu yang amat mulia, sakral dan penuh kulturalis dalam pelaksanaannya. Dikatakan mulia karena perkawinan bagi masyarakat etnis Cia Cia memiliki nilai-nilai etik yang harus dijalani dan dinikmati oleh kedua mempelai yaitu, menyangkut silaturrahim dari dua keluarga besar yang terbangun dengan berlangsungnya perkawinan dua insan tersebut. Sebelumnya, tidak terbayangkan akan terjalin silaturrahim dengan begitu akrab dan seperti keluarga sendiri, dan karena itulah diannggap sangat mulia dari suatu perkawinan.

Sebagai perwujudan dari aspek personal ialah bahwa manusia selalu ingin hidup berpasangan atau hidup bersama dengan lawan jenis. Dengan harapan kelak memperoleh keturunan yang bisa diharapkan sebagai kelanjutan kehidupannya yang bersuku-suku dan berbangsa-bangsa. Secara sosial perkawinan adalah dasar pondasi bagi masyarakat karena dalam perkawinan itu terbentuk tali ikatan antar individu secara kuat. Tata cara perkawinan di Indonesia tergolong beraneka antara satu dengan yang lainnya oleh karena di Indonesia mengakui adanya bermacam-macam agama dan kepercayaan yang tata caranya berbeda. Hal yang demikian dimungkinkan dalam Negara Kesatuan Republik Indonesia yang berdasarkan Pancasila yang dengan tegas mengakui adanya prinsip kebebasan beragama. Pasangan suami-istri yang telah melangsungkan perkawinan, pada umumnya ingin memiliki keturunan dari perkawinan yang telah mereka lakukan, tetapi ada pula pasangan suami-istri yang hidup bersama tanpa keinginan untuk mendapatkan keturunan.

Tahap pertama dalam perkawinan adalah pinangan, hal ini dimaksudkan agar kedua calon mempelai dapat saling mengenal antara yang satu dengan yang lainnya. Mengenai yang dimaksud tidak hanya mengetahui identitas personalnya saja namun lebih dari itu adalah memahami dan mengetahui karakteristik calon suami maupun calon istri. Hal ini dipandang penting karena keduanya bermaksud melangsungkan perkawinan dan membentuk mahligai rumah tangga yang semula dimaksudkan kekal tanpa berujung dengan perceraian. Berkaitan dengan hal ini Hadikusuma (1990: 20) menyatakan bahwa Perkawinan pinang artinya suatu permintaan atau pernyataan yang diungkapkan oleh pihak laki-laki kepada pihak perempuan dengan menggunakan bahasa adat yang indah, sopan santun dan penuh hormat serta memperkenalkan para anggota yang datang dengan maksud melakukan ikatan perkawinan dengan memberikan suatu tanda pengikat kepada keluarga perempuan yang berupa sejumlah uang, bahan pakaian, ataupun perhiasan. Perkawinan pinang diawali dengan melakukan pemilihan jodoh, meminta, pertimbangan lamaran, dan pertunangan atau peminangan.

Disamping banyaknya proses yang harus dilakukan sebelum melangsungkan perkawinan salah satunya adalah termasuk proses penetapan mahar. Dalam proses penetapan mahar ini sangatlah beragam, penetapan mahar 
dalam masyarakat Cia Cia berbeda dengan penetapan mahar suku lainnya, dikarenakan masyarakatnya atau pola pikir serta adat istiadat yang telah ditetapkan berbeda pula. Penetapan mahar sebelum berlangsungnya perkawinan merupakan suatu hal yang wajib dilakukan dan tidak boleh ditiadakan, karena mahar merupakan tanda cinta, mahar juga merupakan simbol penghormatan dan pengaggungan perempuan yang dilamar ketika menginginkannya menjadi pendamping hidup dan juga sebagai pengakuannya terhadap kemanusiaan dan kehormatannya. Hubunganya dengan persoalan di atas, peneliti melakukan observasi awal pada praktek perkawinan masayarakat etnis Cia Cia. Pada observasi awal tersebut menunjukkan, dalam perkawinan adat etnis Cia-Cia terdapat tata cara tersendiri dalam menentukan jumlah mahar menurut etnis Cia Cia yakni tergantung pada silsilah jabatan adat yang dimiliki oleh orang tua dari anak tersebut dalam masyarakat.

Pika bheka-bheka mempunyai arti "bisikan" atau yang lebih familiarnya kita menyebutnya dengan "lamaran". Kata bisikan yang dimaksud disini adalah menanyakan secara langsung pada keluarga perempuan tentang status perempuan tersebut. Kemudian dari pihak laki-laki akan mengutus satu orang untuk ke rumah perempuan tersebut sebagai juru bicara dalam mengutarakan keinginan laki-laki terhadap perempuan tersebut. Utusan yang ditunjuk bisa berasal dari kedua orangtuanya, keluarga, ataupun kerabat terdekatnya. Setelah melakukan pika bhekabheka, maka pihak perempuan akan memusyawarahkannya terlebih dahulu dengan maksud untuk menimbang akhlak dan perilaku laki-laki tersebut, apakah nantinya akan cocok dengan anak mereka atau tidak.

Jika lamaran dari pihak laki laki ditolak maka dengan demikian pihak lakilaki tidak bisa meneruskannya ke jenjang pernikahan. Akan tetapi, jika lamaranya diterima oleh pihak perempuan, maka pihak laki-laki dapat menikahi perempuan tersebut dengan penentuan mahar yang ditentukan berdasarkan jabatan adat yang dimiliki oleh orang tua dari perempuan tersebut. Jabatan adat dari masyarakatt etnis Cia Cia di Desa Wabula dibagi menjadi 3 (tiga) kelompok yakni: 1) Kaomu (bangsawan) Keturunan Sultan dan Sapati masuk dalam golongan Kaomu (bangsawan); 2) Walaka, keturunan para Bontotoa atau para kepala kampung pada masa itu yang akan menjadi golongan Awalaka; dan 3) Maradika, Keturunan Maradika ini adalah diperuntukan untuk keturunan masyarakat biasa.

Menurut Zuhdi dkk (1996: 25) mengatakana bahwa: "sultan dipilih dari golongan bangsawan yang disebut kaomu, berdasarkan hasil pemilihan dari Dewan Siolimbona. Dewan ini terdiri dari para Bonto yang berjumlah sembilan orang. Mereka ini adalah kepala-kepala wilayah disekitar ibu kota Kesultanan yang berasal dari golongan Walaka”.

Persoalan mahar merupakan hal yang sangat strategis pada prosesi perkawinan pinang (pika bheka-bheka) pada etnis Cia Cia di Desa Wabula. Artinya jika persoalan mahar telah selesai dan berhasil ditentukan maka dapat dipastikan seluruh tahapan perkawinan akan berjalan dengan lancar. Sebaliknya, jika pembicaraan mahar tidak memperoleh kata sepakat maka dipastikan proses perkawinan akan gagal atau tersendat.

Tata cara perkawinan dalam suku Cia Cia khususnya di Desa Wabula Kecamatan Wabula Kabupaten Buton pada dasarnya sama dengan tata cara perkawinan daerah-daerah lain di Indonesia, yaitu diawali dengan perkenalan 
antara muda mudinya yang berlanjut kepada masa penjajakan (pacaran untuk istilah zaman sekarang). Dalam masa penjajakan pasangan muda mudi, masingmasing akan memperkenalkan diri kepada orang tua dan keluarganya. Apabila terjalin kesepahaman, maka kedua bela pihak langsung menuju ke jenjang yang lebih serius lagi yakni menuju ke jenjang pertunangan sekaligus menyangkut penetapan mahar adat untuk mempelai perempuannya.

Hal tersebut di atas, didasari oleh pemahaman masyarakat etnis Cia- Cia yang menganggap penentuan mahar menunjukan keberadatan manusia di lingkungan sosial. Begitu sakralnya pemahaman tentang mahar, maka jenis jumlah mahar merupakan hal mutlak yang tidak boleh diganti oleh jenis dan benda apapun juga selain yang ditentukan oleh adat. Bahkan keyakinan masyarakat etnis Cia Cia apabila mengganti mahar dengan jenis di luar yang ditentukan, maka pihak-pihak yang melanggar tersebut akan mengalami kesulitan atau kesialan dalam kehidupan rumah tangga, misalnya: tidak mempunyai keturunan, sulit mendapatkan rezeki dan lain-lain. Hal ini diyakini karena konsep mahar yang ditentukan tersebut memiliki kandungan nilai-nilai filosofis di dalamnya, sehingga wajib ditaati dan dilaksanakan.

\section{Pengertian Mahar}

Mahar secara etimilogi artinya mas kawin. Secara terminologi, mahar ialah pemberian wajib dari calon suami kepada calon istri sebagai ketulusan hati calon suami untuk menimbulkan rasa cinta kasih bagi seorang istri kepada calon suaminya. Dalam istilah ahli fikih disamping perkataan "mahar" juga dipakai perkataan: "shadaq", nihlah; dan faridhah" dalam bahasa Indonesia dipakai dengan perkataan maskawin.

\section{Jenis-jenis Mahar}

Menurut Syarifuddin (2007: 89) membagi mahar menjadi dua yaitu : "pertama, mahar musamma adalah apabila mahar tidak disebutkan pada waktu akad, maka kewajibannya itu harus ditunaikannya selama masa perkawinan sampai putus perkawinan dalam bentuk kematian atau perceraian, kedua, mahar mitsil adalah bila mahar tidak disebutkan jenis dan jumlahnya, maka kewajibannya adalah sebesar mahar syang diterima oleh perempuan lain dalam keluargannya".

\section{Penyebab Perbedaan Jumlah Mahar Dalam Perkawinan Pinang}

Menurut Soekanto (1990: 237) diantaranya yaitu:

\section{Kekayaan}

Kriteria kekayaan berkaitan erat dengan pendapatan. Semakin besar pendapatan seseorang, semakin besar pula kesempatan baginya untuk memiliki sebanyak mungkin harta benda. Selain itu, semakin besar pula peluangnya untuk menduduki strata atas. Sebaliknya, orang yang tidak memiliki harta akan menempati lapisan masyarakat bawah, seperti golongan buruh atau golongan rakyat jelata.

2. Kekuasaan

Kekuasaan berkaitan dengan kemampuan seseorang untuk menentukan kehendaknya terhadap orang lain (yang dikuasai). Kekuasaan didukung oleh unsur lain, seperti kedudukan atau posisi dalam masyarakat. Anggota masyarakat yang 
memiliki kekuasaan dan wewenang terbesar akan mempati lapisan sosial yang paling atas. Sebaliknya, anggota masyarakat yang tidak mempunyai kekuasaan atau hanya menjadi bawahan akan menempati lapisan yang lebih rendah.

3. Keturunan

Dalam masyarakat feodal, anggota masyarakat dari keluarga Raja atau kaum bangsawan akan menempati lapisan atas. Contoh konkret feodalisme dalam hal keturunan adalah gelar Andi pada masyarakat Bugis, Raden pada masyarakat Jawa, dan lain sebagainya.

4. Pendidikan

Dalam masyarakat yang menghargai ilmu pengetahuan atau pendidikan, orang yang memiliki keahlian atau profesi akan mendapatkan penghargaan yang lebih besar dibandingkan orang yangb tidak memiliki keahlian, berpendidikan rendah, ataupun buta huruf. Contoh orang yang termaksud golongan ini adalah peneliti, cendekiawan atau dosen, dokter, hakim dan atlet.

\section{Konsep Status Sosial}

Menurut Roucek dan Warren (1984: 79) menyatakan bahwa Status adalah kedudukan seseorang dalam suatu kelompok dan hubungannya dengan anggota lain dalam kelompok itu, atau kedudukan suatu kelompok berbanding dengan kelompok lain yang lebih banyak jumhlahnya. Oleh karena kedudukan seseorang dalam suatu kelompok itu berkaitan dengan apa yang dilakukannya, maka status berkaitan erat dengan peranan. Status biasanya adalah apa yang dikatakan sebagai kedudukan martabatnya, lebih atau kurang pertinggian-perendahan dan lain-lain.

\section{Proses Penyelesaian Perbedaan Jumlah Mahar Pada Masyarakat Buton}

Menurut Fahmihuddin (2011: 334-335) juga menyatakan bahwa Perkawinan silang antara dua lapis sosial sangat sulit untuk dihindari terjadi seiring dengan perubahan kehidupan sehari-hari masyarakat Buton. Oleh karena itu, perkawinan antara lapis sosial yang sering terjadi adalah antara kelompok kaomu dan walaka. Seorang laki-laki yang memiliki status sosial (kamia) kaomu kawin dengan perempuan dengan status sosial (kamia) walaka dapat dengan menggunakan mahar yang besarnya sesuai dengan besarnya mahar yang berlaku pada kelompok walaka yaitu 32 boka, sedangkan apabila laki-lakinya adalah yang memiliki status sosial (kamia) walaka kawin dengan wanita yang memiliki status sosial (kamia) kaoumu maka laki-laki tersebut akan melaksanakan kewajiban membayar mahar pada kelompok kaomu ditambah denda $100 \%$.

\section{Proses Pelaksanaan Perkawinan Pinang}

Menurut Sere (2016: 153-154) mengkaitkannya dengan prosesi perkawinan etnis Cia Cia yakni terdiri dari 4 (empat) jalur yaitu: pohinada, hende hulu alo, lemba dholango dengan uraian sebagai berikut:

1. Jalur pohinada, yaitu pelaksanaan perkawinan atas dasar suka sama suka oleh kedua belah pihak keluarga. Adapun proses perkawinan melalui jalur pohinada ini, tahapan-tahapannya dilaksanakan secara lengkap yaitu; kabeka-beka, tauano pulu/bawaano ringgi, langgoa, kawia, pokembaa. Adapun mahar (popolo) dalam pelaksanaan perkawinan adalah empat puluh lima boka. 
2. Jalur "kapinunu", yaitu pelaksanaan perkawinan atas dasar suka sama suka oleh kedua belah pihak keluarga. Namun, proses perkawinan melalui jalur kapinunu ini, tahapan-tahapannya dilaksanakan tidak secara lengkap dari awal sampai akhir, melainkan ada satu tahapan yang sengaja dilewati yaitu pada tahapan "langgoa", yaitu dilaksankan setelah acara peminangan sekitar empat hari, selanjutnya pihak perempuan memanggil laki-laki sebagai calon suami ke rumah perempuan sebagai calon istri, namun karena pihak laki-laki adalah dari keluarga kurang mampu sehingga laki-laki dipanggil keluarga perempuan agar dapat mengetahui alamat rumah, dan sekaligus dapat mengetahui tingkat kemampuan atau keadaan laki-laki sebagai calon pengantin dan sekaligus sebagai calon suami. Dalam jalur "kapinunu" ini calon suami tetap membayar mahar (popolo) sebesar empat puluh lima boka kepada (calon) istrinya.

3. Jalur Hende Hulu Alo, yaitu perkawinan yang dilaksanakan secara tertutup sehingga hanya diketahui oleh kedua orang tua/wali dari kedua belah pihak saksi, dan keluarga dekat serta orang yang berwenang menikahkan kedua pasangan tersebut. Prosessi perkawian tersebut dilakukan sebagai berikut:

a) Calon suami istri adalah berasal dari keluarga yang tidak mampu (miskin harta) sehingga kedua belah pihak keluarga bersepakat bertemu untuk membicarakan hari perkawinan, tanpa terlebih dahulu mengadakan acara peminangan melainkan langsung dikawinkan oleh pihak yang berwenang. Calon suami menyediakan mahar (popolo) sebanyak empat puluh lima boka untuk memberikan kepada (calon) istrinya.

b) (popolonya) sudah dibayar oleh mantan sebagai calon istri sudah pernah menikah (janda). Bagi calon istri yang sudah menjanda maka calon suami tidak Wanita lagi membayar mahar (popolo), karena mahar suaminya. sehingga diharuskan untuk mereka berdua segera Wanita bersama laki-laki yang bukan muhrim berdua-duaan di tempat tertutup/sunyi (dianggap berzina) kemudian ada yang mengetahui mereka sebagai saksi-saksi dinikahkan, dan bagi calon suami tidak boleh membayar mahar (popolo).

4. Jalur Lemba dolango, yaitu ketika laki-laki dari komunitas Wabula mencintai dan menikahi wanita dari keturunan bangsawan keraton Wolio yang berstatus Ode maka ia harus siap menyesuaikan diri dengan adat istiadat perkawinan Wolio, yaitu harus membayar mahar (popolo) sesuai permintaan pihak keluarga perempuan. Jika pihak keluarga perempuan tersebut tidak menyetujui untuk anaknya dikawinkan dengan yang bukan sama-sama keturunan bangsawan yang bergelar (Ode) maka laki-laki Wabula memanggil perempuan untuk pergi melaporkan diri kepada Kepala KUA untuk dapat dikawinkan.

\section{METODE PENELITIAN}

\section{Lokasi Penelitian}

Lokasi penelitian bertempat di Desa Wabula Kecamatan Wabula Kabupaten Buton Provinsi Sulawesi Tenggara telah dilakukan pada bulan Mei sampai bulan Juni tahun 2019. Alasan pemilihan lokasi tersebut karena di lokasi tersebut masih menggunakan hukum adat di dalam menentukan jumlah mahar yang terdapat dalam acara perkawinan pinang pada masyarakat etnis Cia Cia. 


\section{Jenis Penelitian}

Penelitian ini bersifat deskriptif dengan tujuan menggambarkan secara sistematis mengenai alasan penyebab terjadiya perbedaan jumlah mahar pada masyarakat etnis Cia Cia di Desa Wabula Kecamatan Wabula Kabupaten Buton Provinsi Sulawesi Tenggara.

\section{Subyek Penelitian}

Subyek Penelitian ini terdiri dari 2 (dua) orang tokoh adat etnis Cia Cia di Desa Wabula sebagai pelaku yang mengatur tata cara adat dalam perkawinan pinang, 1 (satu) orang Pegawai Pencatat Nikah, 1 (satu) orang Imam/khatib Desa Wabula, dan 1 (satu) orang Kepala Kantor Urusan Agama (KUA) Kecamatan Wabula.

\section{Metode Pengumpulan Data}

Untuk memperoleh data yang dibutuhkan dalam penelitina ini digunakan teknik pengumpulan data sebagai berikut :

1. Wawancara, yaitu dengan mengadakan tanya jawab secara langsung dengan responden dan informan, untuk mendapatkan data tentang penyebab terjadinya perbedaan jumlah mahar dalam perkawinan pinang serta tahapan-tahapan dalam prosesi penetapan jumlah mahar dalam perkawinan pinang (pika bheka-bheka) berdasarkan adat Cia Cia di Desa Wabula Kecamatan Wabula Kabupaten Buton.

2. Dokumenter, yaitu pengumpulan data yang diperoleh dari dokumen-dokumen yang ada atau catatan-catatan yang tersimpan, baik itu berupa buku, suratsurat, dan lain sebagainya yang ada kaitannya dengan penelitian ini.

\section{Teknik Analisis Data}

Teknik analisis data yang digunakan dalam penelitian ini adalah analisis yang bersifat kualitatif yaitu memberikan gambaran deskriptif secara jelas tentang keseluruhan proses penentuan mahar dalam pelaksanaan kawin pinang yang dimulai dari pemilihan jodoh, meminta pertimbangan pelamaran, dan pertunangan atau peminangan.

1. Objek penyebab terjadinya perbedaan jumlah mahar:

a. Sub objek kelompok Kaоmu (bangsawan);

b. Sub objek kelompok Awalaka;

c. Sub objek kelompok Maradika

2. Objek penyelesaian perbedaan jumlah mahar dalam kawinan pinang (pika bheka-bheka) yang meliputi :

a. Sub objek penyelesaian jumlah mahar perkawinan pinang (pika bhekabheka) antara laki-laki dari kelompok Каоти dengan perempuan dari kelompok Walaka;

b. Sub objek penyelesaian jumlah mahar perkawinan pinang (pika bhekabheka) antara laki-laki dari kelompok Каоти dengan perempuan dari kelompok Maradika;

c. Sub objek penyelesaian jumlah mahar perkawinan pinang (pika bhekabheka) antara laki-laki dari kelompok Walaka dengan perempuan dari kelompok Kaomu; 
d. Sub objek penyelesaian jumlah mahar perkawinan pinang (pika bhekabheka) antara laki-laki dari kelompok Walaka dengan perempuan dari kelompok Maradika;

e. Sub objek penyelesaian jumlah mahar perkawinan pinang (pika bhekabheka) antara laki-laki dari kelompok Maradika dengan perempuan dari kelompok Kaomu;

f. Sub objek penyelesaian jumlah mahar perkawinan pinang (pika bhekabheka) antara laki-laki dari kelompok Maradika dengan perempuan dari kelompok Walaka.

\section{HASIL PENELITIAN DAN PEMBAHASAN}

\section{Prosesi Pelaksanaan Perkawinan Pinang (pika bheka-bheka)}

Tahapan-tahapan dalam proses pelaksanaan perkawinan pinang (pika bheka-bheka) yaitu: 1) Kabheka-bheka (perkenalan); 2) Bawaano ringgi/tauano pulu (pelamaran); 3) Langgoa; 4) Kawia (perkawinan) dan Penentuan popolo (mahar); dan 5) Prosesi Pembayaran popolo (mahar).

\section{Stratifikasi Sosial Masyarakat Cia Cia}

Di dalam masyarakat etnis Cia Cia di Desa Wabula Kecamatan Wabula Kbupaten Buton terdapat stratifikasi sosial. Stratifikasi sosial tersebut dapat dilihat dengan adanya beberapa golongan yang terdapat pada masyarakat tersebut yakni golongan Kaomu, golongan Walaka, dan golongan Maradika.

\section{Penyebab Terjadinya Perbedaan Jumlah Mahar Dalam Perkawinan Pinang} Etnis Cia Cia

Penyebab perbedaan jumlah mahar yang terdapat pada etnis Cia Cia Di Desa Wabula Kecamatan Wabula adalah disebabkan oleh faktor kekuasaan dan keturunan yang mendominasi pada masa pemerintahan pada masa itu. Kekuasaan yang dimaksudkan adalah jabatan-jabatan yang ada pada masyarakat Wabula. Jabatan-jabatan itu terdiri dari jabatan sultan, sapati dan bontotoa. Jabatan sultan sendiri memiliki nilai mahar sebesar 150 bhoka, jabatan sapati memiliki nilai mahar mahar sebesar 125 bhoka sedangkan untuk jabatan bontotoa memiliki nilai mahar sebesar 100 bhoka.

\section{Proses Penyelesaian Perbedaan Jumlah Popolo (Mahar) Pada Masyarakat Etnis Cia Cia}

Apabila laki-laki golongan Walaka menikah dengan perempuan dari golongan Каоти maka penyelesaian perbedaan jumlah popolo (mahar) akan diselesaikan dengan menggunakan sistem mardika manadikana (kesepakatan adat berdasarkan yang ditetapkan oleh tokoh adat).

1. Proses Penyelesaian Perbedaan Popolo (mahar) antara laki-laki Kaomu dengan perempuan Walaka.

Apabila laki-laki golongan Kaomu menikah dengan perempuan dari golongan Walaka maka penyelesaian perbedaan jumlah popolo (mahar) akan diselesaikan dengan menggunakan sistem mardika manadikana (kesepakatan adat berdasarkan yang ditetapkan oleh tokoh adat). Hasil akhir dari mardika manadikana akan menyimpulkan bahwa: jika para tokoh adat didalam menyelesaikan perbedaan popolo (mahar) menyimpulkan bahwa laki-laki dari golongan Каоти mengikuti mahar yang dimiliki oleh perempuan dari 
golongan Walaka yakni sebesar 100 bhoka, tapi apabila hasil kesepakatan tokoh adat tersebut mengatakan bahwa perempuan dari golongan Walaka harus mengikuti mahar dari golonngan Kaomu yang memiliki jabatan Sultani maka mahar yang akan diberikan adalah sebesar 150 bhoka tetapi kalau perempuan tersebut menikah dengan laki-laki golongan Каоти yang memiliki jabatan Sapati maka mahar yang akan diberikan adalah sebesar 125 bhoka.

2. Proses Penyelesaian Perbedaan Popolo (mahar) antara laki-laki Kaomu dengan perempuan Maradika.

Apabila laki-laki golongan Kaomu menikah dengan perempuan dari golongan Walaka maka penyelesaian perbedaan jumlah popolo (mahar) akan dislesaikan dengan menggunakan sistem mardika manadikana (kesepakatan adat berdasarkan yang ditetapkan oleh tokoh adat). Hasil akhir dari mardika manadikana akan menyimpulkan bahwa: jika para tokoh adat didalam menyelesaikan perbedaan popolo (mahar) menyimpulkan bahwa laki-laki dari golongan Каоти mengikuti mahar yang dimiliki oleh perempuan dari golongan Walaka yakni sebesar 100 bhoka, tapi apabila hasil kesepakatan tokoh adat tersebut mengatakan bahwa perempuan dari golongan Walaka harus mengikuti mahar dari golonngan Kaоmu yang memiliki jabatan Sultani maka mahar yang akan diberikan adalah sebesar 150 bhoka tetapi kalau perempuan tersebut menikah dengan laki-laki golongan Kaomu yang memiliki jabatan Sapati maka mahar yang akan diberikan adalah sebesar 12 bhoka 4 kupa.

3. Proses Penyelesaian Perbedaan Popolo (mahar) antara laki-laki Walaka dengan perempuan Kaomu.

Apabila laki-laki golongan Walaka menikah dengan perempuan dari golongan Каоти maka penyelesaian perbedaan jumlah popolo (mahar) akan diselesaikan dengan menggunakan sistem mardika manadikana (kesepakatan adat berdasarkan yang ditetapkan oleh tokoh adat). Hasil akhir dari mardika manadikana akan menyimpulkan bahwa: jika para tokoh adat didalam menyelesaikan perbedaan popolo (mahar) menyimpulkan bahwa laki-laki dari golongan Walaka mengikuti mahar yang dimiliki oleh perempuan dari golongan Kaоmu yakni sebesar 150 bhoka untuk keturunan Sultani dan 125 bhoka untuk keturunan Sapati, tapi apabila hasil kesepakatan tokoh adat tersebut mengatakan bahwa perempuan dari golongan Kaomu harus mengikuti mahar laki-laki dari golonngan Walaka maka mahar yang akan diberikan adalah sebesar 100 bhoka.

4. Proses Penyelesaian Perbedaan Popolo (mahar) antara laki-laki Walaka dengan perempuan Maradika.

Apabila laki-laki golongan Walaka menikah dengan perempuan dari golongan Maradika maka penyelesaian perbedaan jumlah popolo (mahar) akan diselesaikan dengan menggunakan sistem mardika manadikana (kesepakatan adat berdasarkan yang ditetapkan oleh tokoh adat). Hasil akhir dari mardika manadikana akan menyimpulkan bahwa: jika para tokoh adat didalam menyelesaikan perbedaan popolo (mahar) menyimpulkan bahwa laki-laki dari golongan Walaka mengikuti mahar yang dimiliki oleh perempuan dari golongan Maradika yakni sebesar 12 bhoka 4 kupa, tapi apabila hasil kesepakatan tokoh adat tersebut mengatakan bahwa perempuan dari golongan 
Maradika harus mengikuti mahar laki-laki dari golonngan Walaka maka mahar yang akan diberikan adalah sebesar 100 bhoka.

5. Proses Penyelesaian Perbedaan Popolo (mahar) antara laki-laki Maradika dengan perempuan Kaomu.

Apabila laki-laki golongan Maradika menikah dengan perempuan dari golongan Каоти maka penyelesaian perbedaan jumlah popolo (mahar) akan diselesaikan dengan menggunakan sistem mardika manadikana (kesepakatan adat berdasarkan yang ditetapkan oleh tokoh adat). Hasil akhir dari mardika manadikana akan menyimpulkan bahwa: jika para tokoh adat didalam menyelesaikan perbedaan popolo (mahar) menyimpulkan bahwa laki-laki dari golongan Maradika mengikuti mahar yang dimiliki oleh perempuan dari golongan Kaотu yakni sebesar 150 bhoka untuk keturunan Sultani dan 125 bhoka untuk keturunan Sapati, tapi apabila hasil kesepakatan tokoh adat tersebut mengatakan bahwa perempuan dari golongan Каоти harus mengikuti mahar laki-laki dari golongan Maradika maka mahar yang akan diberikan adalah sebesar 12 bhoka 4 kupa

6. Proses Penyelesaian Perbedaan Popolo (mahar) antara laki-laki Maradika dengan perempuan Maradika.

Apabila laki-laki golongan Maradika menikah dengan perempuan dari golongan Maradika maka penyelesaian perbedaan jumlah popolo (mahar) akan diselesaikan dengan menggunakan sistem mardika manadikana (kesepakatan adat berdasarkan yang ditetapkan oleh tokoh adat). Hasil akhir dari mardika manadikana akan menyimpulkan bahwa: jika para tokoh adat didalam menyelesaikan perbedaan popolo (mahar) menyimpulkan bahwa perempuan dan laki-laki dari golongan Maradika sama-sama memiliki mahar 12 bhoka 4 kupa yang jika dirupiahkan akan mencapai Rp. 274.000, 00.

\section{PENUTUP}

\section{Kesimpulan}

Berdasarkan pembahasan dan hasil penelitian, maka penulis dapat menyimpulkan beberapa hal sebagai berikut:

1. Penyebab perbedaan jumlah mahar yang terdapat pada etnis Cia Cia Di Desa Wabula Kecamatan Wabula adalah disebabkan oleh faktor kekuasaan dan keturunan yang mendominasi pada masa pemerintahan pada masa itu. Hal ini bisa dilihat dari pemberian tahta oleh para raja/sultan yang menentukan orang yang memutuskan untuk menetapkan seseorang masuk ke dalam golongan bangsawan atau bukan. Jadi kekuasaan dan keturunan sangat memiliki peran besar dalam penentuan golongan dalam suatu masyarakat.

2. Apabila terjadi perkawinan berbeda golongan dapat diselesaikan sebagai berikut: 1) Proses Penyelesaian Perbedaan Popolo (mahar) antara laki-laki Kaomu dengan perempuan Walaka; 2) Proses Penyelesaian Perbedaan Popolo (mahar) antara laki-laki Kaотu dengan perempuan Maradika; 3) Proses Penyelesaian Perbedaan Popolo (mahar) antara laki-laki Walaka dengan perempuan Kaomu; 4) Proses Penyelesaian Perbedaan Popolo (mahar) antara laki-laki Walaka dengan perempuan Maradika; 5) Proses Penyelesaian Perbedaan Popolo (mahar) antara laki-laki Maradika dengan perempuan Maradika.

Dengan adanya sistem mardika manadikana dalam menyelesaikan perkara perkawinan antara golongan yang berbeda jumlah mahar, maka tidak ada lagi konflik 
dalam penyelesaian perkara tersebut karena kedua belah pihak telah merasa damai dengan ketentuan adat yang telah ditetapkan oleh para tokoh adat, sehingga kehidupan masyarakat di Desa Wabula Kecamatan Wabula Kabupaten Buton berjalan dengan harmonis.

\section{Saran}

Terdapat beberapa hal yang penulis sarankan setelah menelaah dan menganalisis penelitian, yaitu:

1. Perlu adanya upaya-upaya persuasif dalam rangka mensosialisasikan tawaran konsep pembaharuan praktek mahar dalam perkawinan adat Cia Cia kepada masyarakat etnis Cia Cia.

2. Perlu adanya forum musyawarah adat yang dilambangkan melalui sarana hukum peraturan daerah Kabupaten Buton dalam rangka membalas tawarantawaran konsep perbedaan mahar yang ideal yang sesuai dengan falsafah hidup masyarakat etnis Cia Cia yaitu agama sebagai tata aturan tertinggi yang mengajarkan nilai-nilai keadilan, kesetaraan atau persamaan.

\section{DAFTAR PUSTAKA}

Hadikusuma, Hilman. 2007. Hukum Perkawinan Indonesia Menurut Perundangan, Hukum Adat, Hukum Agama. Penerbit CV.Mandar Maju, Bandung.

Sere, Idrus. 2016. Islam Dalam Adat Wabula-Butoni. Penerbit Deepublish, Yogyakarta.

Fahmihuddin, Mu’min. 2011 Menafsirkan Kembali Sejarah \& Budaya Buton, BauBau, RESPECT

Roucek dan Warren. 1984. Pengantar Sosiologi. Jakarta: PT. Bina Aksara

Soekanto, Soerjono. 1990. Sosiologi Suatu pengantar. Jakarta: Raja Grafindo Persada.

Syarifuddin, Amir. 2007. Hukum Perkawinan Islam di Indonesia. Jakarta: Kencana Zuhdi, Susanto, dkk. 1996. Kerajaan Tradisional Sulawesi Tenggara. CV. DEFIT PRIMA KARYA, Jakarta. 